Stangret Anna, Mularczyk Agata, Szczęśniak Angelika, Topczewska Katarzyna, Rogulska Karolina. Congenital Abnormalities of the Temporomandibular Joint - single conditions. Journal of Education, Health and Sport. 2020;10(8):393-397. eISSN 2391-8306. DOI http://dx.doi.org/10.12775/JEHS.2020.10.08.047

https://apcz.umk.pl/czasopisma/index.php/JEHS/article/view/JEHS.2020.10.08.047 https://zenodo.org/record/4006418

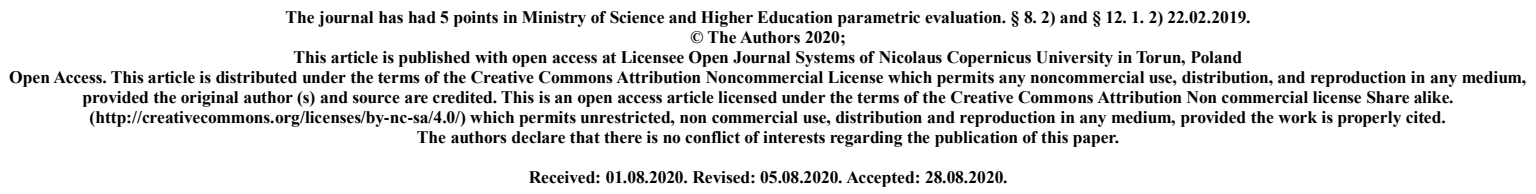

\title{
Congenital Abnormalities of the Temporomandibular Joint - single conditions
}

\author{
Anna Stangret, Agata Mularczyk, Angelika Szczęśniak, Katarzyna Topczewska, \\ Karolina Rogulska
}

Anna Stangret; https://orcid.org/0000-0002-2721-2121; annastangret@wp.pl; Pomeranian Medical University, Department of Human and Clinical Anatomy, Powstańców Wielkopolskich Street 72, 70-111, Szczecin.

Agata Mularczyk; https://orcid.org/0000-0002-8273-6737; amularczyk@ pum.edu.pl; Pomeranian Medical University, Department of Obstetrics and Pathology of Pregnancy, Żołnierska Street 48, 71-210, Szczecin.

Angelika Szczęśniak; https://orcid.org/0000-0002-7854-8864;

angelika.szczesniak.92@gmail.com; Pomeranian Medical University, Department of Microbiology, Immunology and Laboratory Medicine, Powstańców Wielkopolskich Street 72, 70-111, Szczecin.

Katarzyna Topczewska; https://orcid.org/0000-0003-2509-8289;

katarzyna.topczewska@pum.edu.pl; Pomeranian Medical University, Department of Epidemiology and Management, Żołnierska Street 48, 71-210 Szczecin.

Karolina Rogulska; https://orcid.org/0000-0003-1413-7430; karolina.rogulska@ pum.edu.pl; Pomeranian Medical University, Department of Microbiology, Immunology and Laboratory Medicine, Powstańców Wielkopolskich Street 72, 70-111, Szczecin. 


\begin{abstract}
Temporomandibular joint (TMJ), due to its morphological structure, is a bicondylar joint, coupled in every movement. Intensive development of TMJ occurs in the early fetal period. Diseases of the temporomandibular joints differ in etiology and symptoms. The dysfunction of temporomandibular joint may lead to many problems connected with disorders of masseter muscles and bones building this joint and tissues around it. The aim of these studies is to describe several congenital abnormalities of the temporomandibular joint. Congenital deformities of the temporomandibular joint complex can present as a growth of mandible disturbances. They can occur as single condition characterized by hyperplasia or hypoplasia of joint structures. In extreme cases it can occur as agenesis, which is lack of formation. Tempotomandibular joint may be also affected by fibrous dysplasia, form of hyperplasia. They can also occur as a complex symptom with congenital mandible deformity, what can cause the problems with correct diagnosis.

Temporomandibular joint disorders constitute a significant percentage of the viscerocranium diseases. All disorders occurring within these structures are usually associated with severe pain and significant discomfort. In dental practice, it is important to know in detail the symptoms associated with diseases of temporomandibular joint and also differentiate single conditions and complex symptoms.
\end{abstract}

Keywords: temporomandibular joint; TMJ; temporomandibular disorders; TMD; congenital abnormalities

\title{
INTRODUCTION
}

Congenital deformities of the temporomandibular joint (TMJ) complex can present as a growth disturbance of mandible. They can occur as single condition characterized by hyperplasia or hypoplasia of joint structures such as agenesis, dysplasia, hypoplasia or hyperplasia of mandibular condyle [1,2]. They can also occur as a symptom complex with congenital mandible deformity, e.g., hemifacial microsomia, Treacher Collins syndrome or the Pierre Robin sequence. The aim of these studies is to describe several congenital abnormalities of the temporomandibular joint, which occurs as a single condition. The disorders within the temporomandibular joints are large percentage of the viscerocranium conditions. Diseases of the temporomandibular joints differ in etiology and symptoms.

\section{TEMPOROMANDIBULAR JOINT}

Temporomandibular joint, due to its morphological structure, is a bicondylar joint, coupled in every movement. The mechanics of the joint is based on three movements: retrusion, protrusion, excursion. What is more it works all the time. Distinguishing feature of the temporomandibular joint is its articular surface, covered with avascular fibrocartilage. Functional and anatomical structure is more complex than in other human joints $[3,4]$.

The temporomandibular joint differs from other joints in that it develops from two separate nucleuses during long period of ontogenesis. Compared to others, this joint also develops very late. The mandibular cartilage (Meckel) plays an important role in the development of the craniofacial and temporomandibular joint. 
Intensive development of TMJ occurs in the early fetal period. Meckel's cartilage, which forms the basis of the mandible development, appears in embryos at stage 13 (32 days).[4].

\section{CONGENITAL ABNOMALITIES}

Complete agenesis is a lack of formation (which is very rare). In contrast, mandibular aplasia is abnormal or incomplete development of the mandible. In most of the cases, it is classified as a hemifacial microsomia syndromes [5]. Hemifacial microsomia syndrome is the second most common congenital defect of the facial skull (after cleft lip and palate) [6].

Mandible hypoplasia, known as micrognation, is a defect characterized by abnormally small mandible. Micrognation can have a dual nature. On one hand it can occur as a deformation caused by intrauterine mandibular compression (in most of the cases is asymmetrical). On the other hand, it can also have the character of malformation. Due to the fact that the high degree of underdevelopment of the jaw causes the tongue not to fit into the mouth, in children it requires a distinction with macroglossia, i.e. a condition in which the tongue is abnormally large [7].

Condylar hypoplasia is a disorder in which the mandibular head has normal structure but reduced size. The acetabulum has also reduced size. In unilateral hypoplasia asymmetry is presented. The reason for the occurrence of mandibular head underdevelopment are developmental disorders, congenital defects and acquired diseases. This disorder may be hereditary. Condylar hypoplasia is often associated with underdevelopment of the mandibular body and rami. There are symptoms of dysfunction in the area of the temporomandibular joint, and over time, osteoarthritis. Treatment of this condyle requires orthodontic treatment, usually also surgical intervention and bone graft $[8,9]$.

Condylar hyperplasia is a rare disease and is characterized by an excessive bone mass growth. Over-enlargement (less often deformation) of the mandibular head can indirectly affect the fovea, that adapts to the abnormal shape of the head. In the majority of cases, it occurs unilaterally, which leads to asymmetry. Unaesthetic appearance is the most common reason for patients to see the doctor in the early stages. Unilateral hyperplasia also causes occlusion disorders, myofascial pain in the face, as well as pain in the area of the temporomandibular joint. The etiology is associated mostly with overactive cartilage. Endocrine disorders, genetic factors and injuries are among the factors considered as favourable for the incidence of condylar hyperplasia. Usually, excessive mandible growth will resolve on its own with the end of bone development. Treatment is undertaken after the end of the condylar growth and requires orthodontic and surgical intervention $[8,9,10]$.

Fibrous dysplasia is a form of hyperplasia. It is a disease associated with a genetic defect. It is characterized by a mild, slowly growing swelling at the site of occurrence. Abnormal bone formation begins in utero, but the disease occurs in children and young adults. Excessive growth of bone tissue instead of strengthening the bone leads to its weakening due to disturbed architecture [5]. The most common are moderate pain in the temporomandibular joint, local swelling of soft tissues, increased masseter muscle tension and bone deformities [11]. The progress of fibrous dysplasia is usually slow and stabilizes after the end of sexual maturation, in other cases it may lead to huge deformities and become malignant. Treatment usually requires surgical intervention. But it depends on the speed of tumour growth, its location and patient expectations. 
In young people with slow development, the patient is monitored, hoping to inhibit the process during puberty. Surgical treatment is used only with significant disorders. However, 2-3 years after the surgery, the disease recurs even in $30 \%$ of the cases $[12,13]$.

\section{SUMMARY}

Temporomandibular joint disorders constitute a significant percentage of the viscerocranium diseases. According to estimates, every fifth person in the world suffers from at least one symptom of temporomandibular joint dysfunction [14]. All disorders occurring within these structures are usually associated with severe pain and significant discomfort. In dental practice, it is important to know in detail the symptoms associated with diseases of temporomandibular joint.

When diagnosing temporomandibular joint disorders, it is important to consider a much wider range of pathologies, characterized by similar symptoms in both the head and neck area [15]. First of all, it is necessary to distinguish the presence of systemic diseases and intracranial pathologies [16]. This approach is very important from a clinical point of view, due to the reduced risk, the occurrence of cases in which, the dentist does not recognize lifethreatening conditions, because of focusing solely on the treatment of the disorder in the temporomandibular joints only [15]. 


\section{REFERENCES}

1. Mandel S, Sataloff RT. Minor head trauma: assessment, management, and rehabilitation. Springer; 1993.

2. Bumann A, Lotzmann U, Mah J. TMJ disorders and orofacial pain: the role of dentistry in a multidisciplinary diagnostic approach. Thieme; 2002.

3. Gala A, Czupryna S, Gołda W. Artroskopia stawu skroniowo-żuchwowego - zarys postępowania. Poradnik Stomatologiczny. 2002;8. Polish.

4. Woźniak W, Wierusz A, Mikliński P. Rozwój prenatalny stawu skroniowo-żuchwowego. Rozwój stawu w okresie od 7. do 12. tygodnia. Dental Forum. 2005;32(1). Polish.

5. Guzman UA, Gremillion HA. Zaburzenia czynności stawu skroniowo-żuchwowego klasyfikacja diagnostyczna. Część 2. Dental Tribune Polska. 2008;6(4):9-11. Polish.

6. Turska-Malinska R, Cudzidło D. Hemifacial microsomia - a literature review. Dental Forum. 2015;14(1).

7. Korniszewski L. Dziecko z zespołem wad wrodzonych. Diagnostyka dysmorfologiczna. Warszawa: PZWL;2004. Polish.

8. Okeson J. Management of Temporomandibular Disorders and Occlusion. Journal of Prosthetic Dentistry. 2008;69(1).

9. Różyło T, Różyło-Kalinowska I. Radiologia stomatologiczna. Warszawa: PZWL;2008:172-176. Polish.

10. Pokrowiecki R. Przerost wyrostka kłykciowego żuchwy - diagnostyka i leczenie. Medical Tribune Stomatologia. 2018;01. Polish.

11. Betkowski A, Wędrychowicz B, Pogorzelski A. Przypadki dysplazji włóknistej kości twarzoczaszki. Wiadomosci Lekarskie. 1987;40(22). Polish.

12. Syryńska M, et al. Dysplazja włóknista kości szczek w praktyce ortodontycznej. Onkologia Polska. 2008;11(1). Polish.

13.Kowalik S, Kowalczyk R. Agresywna postać zwyrodnienia włóknistego kości twarzy. Czas Stomatol. 1998;51:184-187. Polish.

14. Gonçalves D, et al. Symptoms of temporomandibular disorders in the population: an epidemiological study. Journal of orofacial pain. 2010;24(3).

15. Panek H, Maślanka T. Ewolucja terminologii i klasyfikacji schorzeń stawów skroniowo-żuchwowych w świetle piśmiennictwa i własnych przemyśleń. Dent. Med. Probl. 2004;41(1):9-16. Polish.

16. Laskin DM. Etiology of the pain-dysfunction syndrome. JADA. 1969;79(1):147-153. 